\title{
Fusion and Reform
}

\section{The Potential for Identity Fusion to Reduce Recidivism and Improve Reintegration}

\section{Harvey Whitehouse and Robin Fitzgerald}

\begin{abstract}
Aвstract: Recent theoretical advances in anthropology and group psychology suggest that sharing self-defining experiences creates identity fusion, a powerful form of social glue motivating prosocial action. Here, we present results of in-depth interviews with a sample of 31 former inmates of prisons in an Australian state and explore the theoretical implications of this work for interventions designed to reduce recidivism amongst ex-offenders. Our approach focusses on the implications of fusion theory both for desistance amongst released prisoners and for reinclusion into the community. We consider various ways in which existing interventions could be enhanced by applying this new theoretical knowledge and harnessing the bonding power of shared experience. We also point to features of current practice throughout the criminal justice system that encourage the adoption of inauthentic identities and thereby obstruct the potential for fusion to energise and embolden efforts at reform.
\end{abstract}

KeYWords: anthropology, desistance, identity, psychology, recidivism, social cohesion

What is to be done about recidivism? We argue that a potent form of social glue, known as 'identity fusion', can motivate ex-offenders and, crucially, receiving communities post-release to develop relationships based on shared experience to strengthen commitment to prosocial outcomes. These motivations could underpin a model of rehabilitation and reintegration for offending behaviour.

Identity fusion, commonly described as a 'visceral sense of oneness' with the group, was first conceptualised and measured by group psychologists (Swann et al. 2009). But theories of its underlying causes have been largely inspired by anthropological studies of ritual and social cohesion (Whitehouse and Lanman 2014), especially the theory of 'modes of religiosity' as developed and refined by social and cultural anthropologists specialising in a diversity of ethnographic regions including Madagascar (Bloch 2004), Melanesia (Barth 2002; Lewis 2004; Whitehouse 1995), West Africa (Goody 2004; Peel 2004) and Asia (Bayly 2004;
Howe 2004; Laidlaw 2004). This theory predicts that self-defining experiences (prototypically rites of passage, such as painful initiations) produce particularly intense social cohesion (Whitehouse 2004). It has long been appreciated that episodic and autobiographic memory, including the visceral qualities of flashbulb memory (Conway 1995), play an important role in shaping personal identities and are widely exploited by religious and military rituals to build social cohesion (Whitehouse 1992, 1996). With the emergence of fusion theory, however, it has become increasingly clear that these processes documented ethnographically could be studied more precisely using psychological measures (Whitehouse 2018; Whitehouse and Laidlaw 2007).

As a result, much research has now investigated the fusing effects of emotionally intense life experience in a wide range of groups, including revolutionary insurgents (Whitehouse et al. 2014), football fans (Newson et al. 2016), Muslim fundamentalists

Anthropology in Action, 27, no. 1 (Spring 2020): 1-13 (C Berghahn Books and the Association for Anthropology in Action ISSN 0967-201X (Print) ISSN 1752-2285 (Online) doi:10.3167/aia.2020.270101

This article is distributed under the terms of the Creative Commons Attribution Noncommercial No Derivatives 4.0 International license (https://creativecommons.org/licenses/by-nc-nd/4.0/). For uses beyond those covered in the license contact Berghahn Books. 
(Yustisia et al. 2019), martial arts groups (Kavanagh et al. 2018), victims of terrorism (Jong et al. 2015), and even wildlife conservationists (Buhrmester et al. 2018). This growing body of evidence suggests that the sharing of self-defining memories is capable of generating identity fusion whenever people undergo emotionally intense experiences together (Whitehouse et al. 2017). The policy implications of these findings are becoming increasingly apparent (Whitehouse 2013), but this is the first effort to apply the results of fusion research to the problem of recidivism among ex-offenders.

Numerous studies have shown that identity fusion motivates strong forms of prosocial action and parochial altruism (e.g. Swann et al. 2014; Whitehouse et al. 2014). Here, we consider how factors that increase fusion with others could help ex-prisoners to 'go straight' and improve their ability to make a positive contribution to society at large. At the same time, increasing fusion within the receiving community could also play an important role in reforming and reintegrating offenders. To some extent, elements of correctional programmes and practices already encourage these kinds of relationships. Unfortunately, there are features of the criminal justice system that can unintentionally prevent this from happening by widening a gulf between offenders and the communities from which they come. They do so by requiring offenders to adopt inauthentic identities (e.g. to satisfy parole boards) and by attempting to obstruct access to salient social networks (e.g. via exclusion orders) rather than by influencing the goals of these networks in positive ways. Here, we offer a diagnosis of the problem based on a theoretical framework developed by a transdisciplinary team of social and behavioural scientists, and propose a road map for enhancing existing approaches to offender rehabilitation.

Criminologists have long debated how best to provide effective correctional interventions. The shift in mantras from 'nothing works' (Martinson 1974) to 'what works' (Cullen and Gendreau 2001) is underpinned by the risk paradigm and by experimental research demonstrating that at least some correctional programmes and interventions can and do reduce recidivism. Our goal in this article is not to criticize existing approaches, and still less to replace them; rather, it is to demonstrate how one tool (identity fusion resulting from the recognition of shared experiences) can be used more effectively to reduce offending. This tool is not entirely new in criminal justice practice - we consider examples of initiatives that already harness the power of shared experience in various ways, and argue that a fuller understanding of the psychological mechanisms involved could lead to even more effective interventions. Moreover, the approach we recommend should be seen as potentially augmenting rather than replacing others that have proven to be effective in the past.

There is certainly scope for improvement in the way ex-prisoners are reintegrated into society. Despite the substantial body of research evidence on effective interventions (Mackenzie 2006), recidivism rates remain high - for example, about two-thirds of released prisoners will be re-arrested within three years in the United States (Durose et al. 2014). Those working from within the more recent desistance paradigm have produced a series of arguments that the singular focus on 'what works' misses important questions about the nature of offending and of how people change (Maruna 2001; Maruna and LeBel 2012; McNeill 2006). From this view, desistancesupporting interventions "need to respect and foster agency and reflexivity; they need to be based on legitimate and respectful relationships; they need to focus on social capital (opportunities) as well as human capital (motivations and capacities); and they need to exploit strengths as well as addressing needs and risks" (McNeill 2006: 55). Nonetheless, studies show that motivation is a persistent barrier to offenders' movement towards desistance (Farrall 2002; Giordano et al. 2002; Healy 2014).

Equally important is the role of the wider community in fostering reintegration and redemption. These are laudable sentiments but also ambitious ones. To start the process, some have argued that there needs to be an effective way of motivating exoffenders and the communities into which they need to be reintegrated to work together towards common goals (Farrall 2002; Giordano et al. 2002; Healy 2014). We view this as the first rung of a tall ladder, and our goal in this article is to contribute tools that can help make and install that 'first rung'. In other words, we are seeking a motivational base capable of nudging people in the direction of positive change.

\section{Fusion among Felons}

Identity fusion is a strong form of alignment with a group, based on the fusion of personal and collective identities (Swann et al. 2009; Swann et al. 2012). Early measures of fusion used a pictorial scale (Figure 1) in which research participants are shown a series of pairs of circles, one small (representing you) and one large (representing a group to which you belong). 

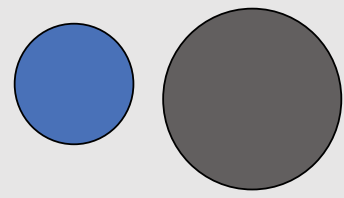

Self

Group

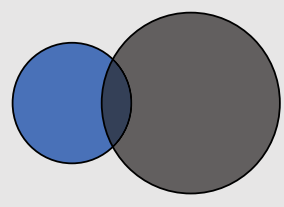

Self

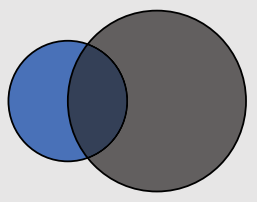

Self

Group
Self Group

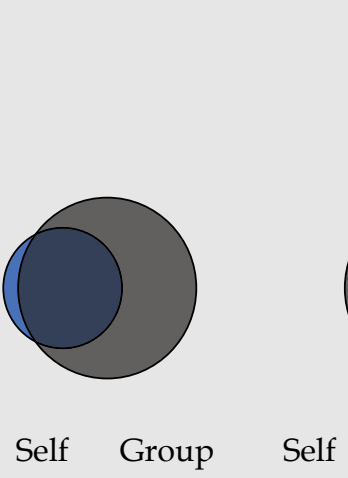

Fused

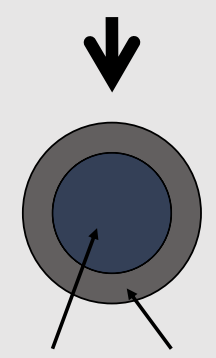

Self
Group

Figure 1. The Pictorial Fusion Scale (Swann et al., 2009).

Each pair of circles in the series differs in degrees of overlap, ranging from no overlap at all (very low fusion) to small circle fully enclosed within the big circle (very high fusion). Participants are invited to say which depiction best characterises their relationship with the group.

Variants of the pictorial fusion scale have used more gradations of overlap or a sliding scale which participants can use to specify the exact point on a continuum where their fusion level falls. A verbal fusion measure (Gómez et al. 2011) has also been developed and validated, in which participants are invited to endorse on a Likert scale how strongly they agree with the following statements (in the original measure, the 'group' specified was 'country' but is substitutable for any group):

My group is me.

I am one with my group.

I feel immersed in my group.

I have a deep emotional bond with my group.

I am strong because of my group.

I'll do more for my group than any of other group members would do.

I make my group strong.

Numerous studies have shown that high levels of fusion with a group motivate extreme forms of self-sacrifice, such as willingness to fight and die to protect other members of the group (Swann et al. 2014). Fusion is thought to play an important role in fighting groups, ranging from conventional armies (Whitehouse et al. 2017), to revolutionary insurgents (Whitehouse et al. 2014), and from extreme football fans (Newson et al. 2016) to suicide terrorists (Whitehouse 2018). But there is also strong evidence that fu- sion can motivate peaceful forms of altruism within the group (Swann and Buhrmester 2015). Indeed, in the absence of an out-group threat, evidence shows that 'fused' individuals are primarily interested in taking care of one another rather than fighting (Reddish et al. 2016; Segal et al. 2018). Multi-country studies suggest that fusion fosters perception of familial ties (Swann et al. 2014), and fusion has been described as a form of psychological kinship (Whitehouse and Lanman 2014). Not surprisingly, therefore, the perception of shared biological traits, as would be found amongst genetically related individuals, has been shown to foster identity fusion (Vázquez et al. 2017) and may help to explain why highly fused social groups commonly invoke idioms of kinship (e.g. common ancestry, bonds of fictive brotherhood). But fusion has also been shown to result from the sharing of personally transformative experiences (Jong et al. 2015; Whitehouse 2018). Indeed, this is probably the most important pathway to fusion in groups of genetically unrelated individuals. When self-defining experiences are shared with other group members, and thus are also defining for the group, this serves to fuse personal and collective identities. To the extent that such experiences have a long-lasting (e.g. lifelong) impact on identity, fusion with a group is often highly stable over time (Newson et al. 2016).

Although no systematic research on identity fusion amongst offenders has been carried out, we conducted in-depth exploratory interviews with a sample of 31 men and women serving parole orders in an Australian state in 2017-2018. The aim of the interviews was to assess participants' perceived fusion with a variety of groups (e.g. family, country and salient friendship networks) using the pictorial fusion scale, but it was also to speak in depth with 
participants about their interpretations of those relationships, their lives, and their experiences of prison and parole. Parolees were recruited through six Corrective Services Probation and Parole offices, and the sample served as a rough representation of the parole population in the state with a greater proportion of men (84 per cent) than women (16 per cent), a greater proportion of those serving shorter sentences of less than three years (65 per cent) than longer sentences (35 per cent), and roughly 16 per cent who identified as Indigenous Australians, an underrepresentation relative to their 31 per cent share of the state's prison population but nonetheless an overrepresentation relative to their 3 per cent share of the general population (Australian Bureau of Statistics 2017). Ethical approval for this research was granted in advance by the relevant university $\mathrm{Hu}-$ man Research Ethics Committee and the state Corrective Services Research Committee. Participants in the study, all parolees over 18 years old, were interviewed following scheduled supervision meetings so as to reduce respondent travel and time burden. All participants were given the opportunity to provide informed consent following a description of the nature and aims of the study in appropriately accessible language. At the end of each interview, participants were given the opportunity to debrief, seek feedback, or ask questions related to the research, as well as to opt out of the study at any time.

In line with our interest in the fusion of personal and group identities, the structured interviews began by focusing on participants' most transformative life experiences, which we described as 'life-changing' events that can be remembered very clearly. We then explored the extent to which the experiences people described were felt to be shared by others, something previous research has shown to be an important mediator of fusion with a group. We were also interested in identities that might obstruct the pathway to fusion, such as inducements by courts and parole boards to adopt inauthentic redemptive life narratives in order to secure reduced sentences. For example, we asked people whether they sometimes needed to put on an act and how that made them feel. We then administered the pictorial fusion scale focused on a series of groups: family, all Australians, and then other groups that they had indicated were important to them (e.g. community, church, work colleagues). The questions then returned to issues of shared experience, this time focusing more specifically on the groups mentioned earlier. In the closing parts of the interview, we explored factors that make reintegration into the community easier or harder and especially what kinds of things could motivate them to want to go straight.

Several themes arose from these interviews, suggesting that identity fusion amongst those who have served custodial sentences may follow very different patterns as compared with the population at large. For a start, fewer than half (42 per cent) of our sample indicated that they were highly fused with their families, a figure that is low compared with levels of fusion with family estimated in previous research sampling general populations worldwide (Swann et al. 2014). For example, most Australians (89 per cent of those sampled) in a multi-country study singled out family as the group they were 'most willing to die for', a measure that correlates highly with levels of identity fusion (Swann et al. 2014: 916; Whitehouse et al. 2014). This finding is not surprising based on consistent research evidence linking dysfunctional family relationships to criminal behaviour (e.g. Hoeve et al. 2009). Poor family relationships are also targeted as a key risk factor in the predominant riskneeds-responsivity models of correctional intervention (Andrews and Bonta 2010; Purvis et al. 2011). Participants in our study articulated several reasons for their lower fusion to family. Not surprisingly, patterns of childhood abuse and precarious family circumstances emerged as common themes. As one participant, explained:

I've had bad experiences when I was growing up with mum and dad. Um, just all the abusive hidings that we used to get when we were young. Um ... and also, when mum, dad and me brothers and sisters left me in New Zealand and moved here in ... I was on the streets then, so I wouldn't know that they came here, to Australia to live. (Male, 40 years)

Some participants described the disconnection from family as the sense that their close kin did not really know their authentic personal selves. For example, as another participant put it:

I also haven't been brought up with my siblings a lot ... and I don't normally talk about ... what I go through to them, so they ... they only know me as me, but they don't know ... the me on the inside. (Male, 37 years)

Equally unusual in our sample, relative to national samples, was the low level of fusion with society at large (Swann et al. 2014). Indeed, a full third of our participants chose the two lowest possible fusion levels with Australia, suggesting a strong sense of alienation from their country of origin or residence. As one participant explained: 
Well I'm an outsider. Even though they - no one on the street knows me, I feel like I'm being judged and looked at like they know - they just know. Or they look at you 'cus you have tattoos, and the way you look. Like, you're a bad person, and cross the road. So - I get that all the time. Like, just random people just cross roads 'cus I'm walking, yeah. (Male, 31 years)

This is a critical point demonstrating alienation from, rather than alignment with, mainstream society. The issue, to which we return below, is how to encourage some recognition of existing commonality or 'shared experience' between members of the community and the offender so as to more effectively bolster and validate a desisting identity following release from prison.

Although fusion with family and country were much lower than what previous studies of Australia's general population have recorded, ex-offenders showed unusually high levels of fusion with members of their social networks, especially those with whom they had shared the ordeals of incarceration. The way participants described bonds of this kind suggested that such relationships can be stronger than bonds of kinship. As one participant put it: 'My friends are more family than what family is, 'cus I've been with them all my life' (Male, 31 years). Or for another participant, some fellow prisoners were 'people that have gone through hell same as me', forging relationships with them that 'absolutely changed my life' (Male, 19 years). Participants also described the feelings of trust that these bonds with other prisoners created, allowing them to feel comfortable sharing deeply felt experiences:

There was a couple of good guys in there I knew even though they did quite bad things ... we could talk about everything. ... I got to know them over six years pretty much. Yes, they were good. They didn't tell anyone else anything. (Male, 29 years)

Previous research has found these kinds of 'familial' bonds also amongst diehard football fans (Newson et al. 2016) and military groups (Whitehouse et al. 2017), and one such study conducted amongst revolutionaries in the 2011 Uprising in Libya showed that on a forced choice question, frontline fighters chose their brothers in arms over actual family members as their most fused group (Whitehouse et al. 2014). We could describe these groups based on fictive kinship as 'fusion families'. Although fusion families can become established naturally in prison as a result of sharing the trials and tribulations of life behind bars, there are also some striking examples of felon-led organisations that generate fusion to the group via emotionally intense ritual and religious experiences. An excellent example of this is provided by churches in American prisons.

Louisiana State Penitentiary (more commonly known as 'Angola', where ancestors of many inmates were originally captured as slaves) is America's largest maximum-security prison. Ninety per cent of those serving sentences at Angola die in custody, with an average sentence length for non-lifers of over 90 years in 2012 (Hallett et al. 2017). Until the 1970s, murder rates at Angola were high, but felon-led religious organisations appear to have been largely responsible for making the prison a much safer environment for both inmates and staff (Hallett et al. 2017). Angola is the only prison in the United States that permits inmates to run their own 'churches' as a result of a 1974 federal consent decree aimed at addressing the appalling conditions in the prison that 'shocked the conscience of any right-thinking person' (Hallett et al. 2017: 2). Federal resources have allowed inmates to design and operate a 'panoply ecumenical worship' (Norris 2016) referred to collectively as the 'Angola Church'.

The Angola Church appears to have played an important role in fostering a sense of community in prison, leading to a safer environment. For instance, Michael Hallett and colleagues (2017) show that prisoners involved in these religious programmes report lower rates of disciplinary convictions and misconduct, but also higher rates of religious self-change or conversion narratives and positive self-identities. In further research, conversion and, to some degree, religiosity are demonstrated to be likely to lead Angola prisoners to 'rehabilitate themselves by helping transform their old, antisocial self into a new, prosocial one' (Jang et al. 2018: 432). Future research should attempt to disambiguate the psychological processes that underpin these prosocial outcomes. A plausible working hypothesis is that felon-led religious activities, and especially the oratorical skills of those delivering sermons in prison, serve to ramp up fusion amongst inmates based on shared experience. Hallett and colleagues describe an 'interdenominational cross-pollination' (2017: 179) that occurs frequently between inmate ministers who often work together, sharing the same physical space and resources as they interact and build connections. Hallett and colleagues capture this sense of connection, or 'camaraderie', from one inmate minister:

I was so green, as green as they come. I was attracted here being the maintenance man. I didn't even know the books of the Bible. But when I was invited and approved to go to school - sitting in class day after 
day after day and working together and struggling together and getting to my wounds and my scars that I could share with many of them through the various tests, and yet it comforted me with a love - and not at all one time forcing me to become Baptist. There's a camaraderie in the midst of the preparing, the equipping, that I learned in seminary that you're just not going to get apart from that. (Hallett et al. 2017: 61)

A recurring theme in inmate ministers' narratives and in the sermons more generally is shared experience, which is of course a known pathway to identity fusion. Angola's inmates know, of course, that many of the ordeals they have personally endured in their lives are commonplace amongst fellow prisoners. Techniques comparable to those used by ministers in the Angola Church to inspire fusion and prosocial action are evident in other religiously inspired interventions such as the Alcoholics Anonymous (AA) 12-step programme that focusses strongly on shared suffering as a means of bonding and motivating participants. As we could predict, recent research on AA meetings has shown that giving help to other members of the group, irrespective of receiving help from others in the group, is a factor that significantly reduces one's likelihood to relapse (Johnson et al. 2018). This is also evident in prison-based peer-support programmes which provide both mentors and mentees greater insight into their lives, helping them to move towards desistance (Devilly et al. 2005).

Thus, it seems that the prison environment can foster a diversity of configurations of personal and group identity, presenting a range of challenges both from a fusion-theory perspective and from the more practical perspective of how best to assist rehabilitation. One configuration we have considered above may be described as 'fusion-free' - that is, individuals who are not fused with any groups or relational dyads and networks. Here, the practical challenge would be to help such individuals appreciate that at least some of the transformative life experiences that have made them who they are today are also shared by suitable others. The goal in this case would be to fuse such individuals to law-abiding or positive models, providing a basis for joining mainstream groups espousing positive values and character virtues.

A second configuration, one that also featured in our Australian sample, was that of the 'fusion family' - individuals who have developed familial bonds in prison. And we have also seen that fusion families can be cultivated within religious organisations managed by prisoners themselves, such as the felon-led Angola Church. In such cases, a reasonable aim might be to harness the bonds of fusion families to motivate prosocial action that is endorsed by the criminal justice system as well as by society at large, not only in the prison environment but following release. Correctional systems are already effective at identifying individuals who ought to be kept apart because of previous or current criminal associations (Andrews and Bonta 2010), but they may also provide a footing for the development of fusion families through prison-based and community programmes that encourage peer connections (Devilly et al. 2005).

Still other identity configurations are possible. For example, in some cases prisoners may become toxically fused - that is, strongly aligned with a street gang, criminal cartel, or terrorist cell bent on acts of violence. Although our sample of ex-offenders did not include such individuals, dangerous forms of identity fusion might be amongst the 'push-andpull factors' that can bedevil efforts to go straight (Roman et al. 2017). In such cases, efforts could be made to develop interventions aimed at defusing group members, for instance by exposing them to evidence that their self-defining life experiences are less shared with the members of violent groups than they previously assumed (Whitehouse 2018).

If a goal of the criminal justice system is to reform prisoners, to reintegrate them into society as loyal and law-abiding citizens, then one effective way to accomplish this would be to nourish fusion with prosocial groups and values and/or to defuse offenders from toxic groups. Arguably, current policy can obstruct this by encouraging the adoption of inauthentic personal identities and focussing excessively on criminality rather than on commonality. Even approaches specifically designed to help ex-offenders to reintegrate into society could be criticised along similar lines. For example, correctional practice throughout Australia relies heavily on interventions based on cognitive-behavioural therapy (CBT; Heseltine et al. 2011). While there is consistent evidence that CBT programmes are effective at reducing recidivism for some groups of offenders, and aid in teaching skills such as emotional regulation and perspective-taking (Hofmann et al. 2012), CBT has also been critiqued on a number of grounds, including that some variants of this form of therapy require prisoners to internalise or accept notions of criminal identity in order to then undergo a process of self-recovery (Kendall 2002). Howard Becker's (1963) now classic labelling theory suggests that, rather than changing behaviour, such interventions may encourage the offender to accept the 'deviant' label and consequently see him or herself as an 'outsider'. These same labels are often promoted in the wider community, which increases the 
difficulty of forming the types of relationships that can help an offender continue the path of desistance that may have started within the institution.

It is vital to appreciate that the fusion process relies on the sharing of authentic self-defining experiences with others. The formation of fusion relationships within prison can serve to be the motivation for offenders to begin to develop a desistance identity. Fusion families established spontaneously through shared experiences in prison engender powerful social bonds based on authentic and potentially durable processes of identity-formation. Family-like ties amongst offenders result not only from sharing the experience of incarceration but also from the realisation that others have gone through similar experiences of abuse growing up and of being rejected or judged by society at large. When fusion families are created in this way, their members are strongly motivated to support one another, even to encourage each other to break out of cycles of crime and incarceration. As one participant in our Australian sample put it:

I've just done close to ten years straight. And I was up with a good mate, and he's a lifer. And I told him: "I'm not gonna bother with parole. I'm just gonna kick back and do full time, "cus it's easier in here." And he's like: "Stuff it, mate. Just get out and live life. I'm in here for the rest of my life, at least you can get out and enjoy it." And ... when he started explaining certain stuff, it kind of . . . stuck out to me. 'Cus I'm 31 and I've spent nearly three quarters of my life in prison, juvenile and adult, and ... I've never had a birthday out since I was 15 . Christmas ... I've lost a lot of my life. My family, everything. So, what he said to me really stuck out. And I've been out seven months now, and it's the longest I've ever been out of prison. (Male, 31 years)

In other words, the shared-experience pathway to fusion in prisons and the criminal justice system more broadly can serve as an important tool for reform and desistance. However, the initiation of the desistance identity that is formed within the prison can only be maintained following release if there is wider validation in the external community. Certainly, correctional practice can, on its own, act to inhibit opportunities for that validation. For instance, the very conditions of parole can expose individuals serving these orders in the community to stigmatising and blocked opportunities that hinder desistance (Opsal 2012). This possibility has been described as the "parole paradox', in which the system of parole, which is ostensibly aimed at reducing the risk of reoffending and encouraging reintegration, at the same time can place individuals in circumstances that actually 'complicate efforts to attain a conventional lifestyle' (Pogrebin et al. 2015: 414). In some cases, these complications may relate to individuals' abilities to foster and maintain crucial relationships with fusion families. This can happen because the conditions of release commonly include various exclusion orders that prevent potentially fused individuals from consorting with each other on the outside. While it may be likely that relationships forged on the inside can be counterproductive to desistance, we should also take seriously the strength of connections (based on shared experiences) within fusion families and the potential for encouragement of prosocial behaviour because of these relationships.

Of course, the challenge lies in differentiating prosocial productive and counterproductive relationships and determining how to foster the former and rechannel the latter. A number of factors are thought to influence the likelihood that fusion motivates violent or peaceful forms of pro-group action. These include perceptions of out-group threat, adoption of violence condoning norms, in-group-out-group segregation, entitativity, and lack of peaceful alternatives (see response to commentaries in Whitehouse 2018). Where there is potential for fusion families to work together for prosocial outcomes, how might that potential be fostered and implemented in practice? Further, can we help the individual who has demonstrated the ability to develop fused relationships on the inside to generalise that ability so as to find new prosocial fusion families on the outside - and if so, how? We propose that, instead of trying to break up fusion families, we should explore ways of harnessing familial bonds among ex-prisoners to motivate forms of prosocial action, not only in order to have them support each other to succeed on the outside, but also to have them be able to assist less fortunate individuals, for example through a range of charitable activities.

\section{Fusion in the Receiving Community}

Managing fusion to achieve positive outcomes has two components. The first is offender-focussed; it is aimed at encouraging offenders to develop relationships where there is a mutual concern to motivate prosocial action. The second, however, focusses on the wider community and its capacity to foster and strengthen prosocial relationships. Where the community is resistant to accepting offenders and forming bonds with them, one challenge might be to establish programs and practices that demonstrate 
common experiences or a sense of shared humanity (Maruna and King 2008). Efforts to reform ex-prisoners can productively focus attention as much on the receiving community as on the offenders themselves, and in particular might explore ways of encouraging potential employers to hire ex-prisoners given their tremendous obstacles to finding and keeping work following release (Western et al. 2001). Identity fusion has an important role to play here as well. The effectiveness of community initiatives that seek to establish relational ties with ex-prisoners may depend greatly on the motivations of those responsible for delivery. If the primary motivations are professional or charitable, and the rewards largely extrinsic (e.g. salaries in the case of social workers, or profits for prospective employers) or reputational (praise or admiration as a 'do-gooder'), then the relational ties forged with ex-offenders may be superficial or transient. This is not to diminish the importance of such work but to say that its effectiveness could be significantly enhanced by strengthening the fusion of communities surrounding offenders as they re-enter society. In tune with this approach are a broad range of initiatives that focus on shared experiences of offenders and the communities around them and which are typically also felon-led or at least emphasise the agency of both offenders and their social networks in equal measure. In this section, we begin with examples of initiatives that would seem to operate in this way, arguing that a fusion-theory approach could further strengthen such interventions. We then consider examples of approaches that are more antipathetical to ours and highlight risks associated with them.

Fusion in the receiving community is often rooted in prior experience of prison life. Indeed, some of the most effective initiatives in the community have been led by and for ex-prisoners to address various issues that affect these 'returning citizens', including employment, housing, education and health care. These groups can function as political advocacy groups, places to position ex-offenders as moral actors or agents of change (Graham et al. 2015), but at the same time they can also serve as places to foster understanding and common ground amongst those with shared experiences. Among others, User Voice, founded in the UK in 2009 by ex-offender Mark Johnson, has as a foundation an ex-offender-led peer support and mentoring programme, recognising that 'offenders like to relate to those who have walked in their shoes'. ${ }^{1}$ User Voice participants speak about the importance of shared experience with other participants in their own narratives of desistance. For example, Jade says:
I want a life. I've got a chance. Mark [Johnson] talks sense and the thing is I wouldn't take that from anyone else. He's been through it and so I know that he's giving me good advice. If it was someone talking to me who hadn't lived his life I wouldn't listen. I'd just think, who are you telling me this? ${ }^{2}$

Initiatives to reduce recidivism that focus on relationships with the receiving community often extend beyond relational networks, such as fusion families, by focussing on shared experience with much larger categorical groups, such as country, ethnic group, or even humanity at large. Although there is some evidence that this kind of 'extended fusion' with imagined communities (Swann et al. 2012) may not be as strong as 'local fusion' with face-to-face groups (e.g. Whitehouse et al. 2014), many studies have shown that extended fusion is nevertheless a potent motivator of pro-group action (Swann et al. 2009), even when it stretches beyond the species barrier to include fusion with other animals (Buhrmester 2018). Examples of initiatives designed to tap into feelings of shared experience with expanded group categories, binding together community members and exoffenders from all walks of life, include profitable new businesses. Since 1982, Greyston Bakery in the United States has originated and developed a system of open hiring in which any willing person, irrespective of criminal history or past, can be employed without asking any questions, and this includes women, men, people of color, people of all faiths and sexual orientations, immigrants and refugees, those living in poverty or who have spent time in prison, and anyone else who has faced barriers to employment'. ${ }^{3}$ Greyston's aim is 'to create the opportunity for people to participate fully in our economy and contribute to our collective values' ${ }^{4}$ The larger story of Greyston is to lead by example and 'to change the world' by promoting a sense of shared commitment and experience in the wider community. ${ }^{5}$

Other initiatives that seek to strengthen the community's capacity to accept ex-offenders back into the fold likely draw on shared experience to elevate fusion-like bonds. Such initiatives might be loosely categorised as 'innovative correctional strategies' involving programmes focussing on a range of special interests from art to horticulture. What they have in common is a mechanism for offenders to work with and alongside members of the community and for the community as a whole. Examples of these initiatives include 'green justice' (cultivating healthy garden produce for disadvantaged groups), animal fostering and welfare, art therapies, entrepreneurship courses, local conservation projects, disaster aid 
provision, and inclusion programmes (White and Graham 2015).

Initiatives that foster fusion and a local community have an important role to play in reducing recidivism, but we also need to consider the role of society at large and especially the impact of nation-wide government policies, which are in turn influenced by public opinion. Given the real barriers to re-entry that ex-offenders can experience including housing, access to services, and employment (Petersilia 2003) and the crucial role that ex-offenders' feelings of being stigmatised can have for reconviction and or reimprisonment (LeBel et al. 2008), it is necessary to break down the walls of separation (White and Graham 2015) between offenders and the countries in which they are citizens. The production of shared experience leading to identity fusion must therefore involve the wider society. Previous research suggests that there may be mechanisms for tapping into the broader public's sense of 'shared experience', when it comes to the re-entry of offenders back into society.

For example, Mike Nellis (2009) has argued that American film, theatre, music and literature since the 1990s has produced a plethora of narratives focussing on the experiences of released prisoners. In this body of work, there is a recurrent focus on personal agony, redemption and public forgiveness. This work can contribute to a public conversation about crime and punishment, but also to a sense of shared humanity. Another example would the United Kingdom's newly launched 'Twinning Project' that seeks to establish links between football clubs and their local prisons, providing coaching and support to help offenders acquire new skills and social relationships to facilitate reintegration after they are released. ${ }^{6}$ The initiative is nation-wide, with backing from central government, the Premier League, and the Football Association, garnering support from tens of thousands for sports fans from across the country. Because team sports are such a powerful mechanism for generating identity fusion (Newson et al. 2016; Whitehouse et al. 2017), this initiative appears to be a particularly strong candidate for strengthening fusion between ex-offenders and society at large.

\section{Conclusion}

We have argued that the theory of identity fusion is a useful tool that can be used to strengthen bonds between offenders and society that leads to an increase in prosocial action including commitment to lawabiding norms and behaviours. Fusion can, in part, ex- plain why some existing correctional practices might work, but it can also be a valuable resource not only for offenders, increasing their capacity to support each other and to contribute to society at large, but also for the communities accepting them back into the fold.

There are strong theoretical grounds for supposing that identity might play an important role in both offending and subsequent recidivism (Stone et al. 2018). Weak alignment with law-abiding groups and their values may be linked to increased risk of criminality. Here, we have sketched out potential mechanisms for improving both the quality of former prisoners' lives and their capacity to reintegrate into a community following release so as to lay the foundations for interventions that take prisoners' authentic memories and identities more seriously. In so far as the authentic identities are prosocial and positive, affirming these positive core identities may strengthen motives to connect to others that will continue to nourish their identities and their capacity for prosocial action. In addition to policy applications, an attractive feature of this theoretical work from a purely scientific perspective is that here we have the opportunity to consider a population in which we can see a wide range of variability in the relationships between personal and group identities and observe how this can influence the fusion mechanism.

Drawing on recent research showing that identity fusion results from the sharing of personally salient experiences, we have argued that exactly this kind of sharing is what is needed to help ex-offenders become more fully reintegrated into society. We have pointed to many examples of existing interventions, especially felon-led initiatives that draw on shared experience and the resulting fusion to assist reform and reduce recidivism. Most if not all such interventions have arisen through trial and error, and could undoubtedly be refined and improved by adopting a more theoretically informed approach. For example, we have suggested that some of the most potent effects of felon-led church groups could be distilled down into elements that do not strictly require a religious component (e.g. appeal to supernatural agency). Conversely, we have suggested that many approaches to prisoner reform that involve the adoption of inauthentic and negative personal identities could impede rather than assist reintegration.

Although our approach seeks to build on desistance theory, our focus on the role of group psychology is distinctive. Desistance theorists have tended to emphasise personal identities and psychological motivations, such as hope and belief in self-efficacy (e.g. Lebel et al. 2008). While we acknowledge the im- 
portance of positive personal attitudes and attributes such as optimism, confidence, and tenacity - we argue that these qualities can be amplified through fusion with a group. Fusion produces an expanded sense of agency and self-efficacy, hence its importance in military settings when heroism is called for and the temptation to run away or give up may be strong (Whitehouse 2018). In that sense, fusion is empowering - it strongly motivates people to press on against the odds. Fusion with law-abiding groups could certainly strengthen the resolve to 'go straight'. So, while having a belief in one's self-efficacy can certainly contribute to desistance, being fused with a group - as an additional measure - can greatly strengthen one's motivation to prioritise others (and potentially also their positive values) over the temptation to act selfishly (including criminally).

Further research is needed to test and refine the theoretical framework set out in this article, and we have pointed to several areas that might be fruitfully prioritised. First, we have argued that longstanding fusion with groups on the outside, as well as support networks associated with fusion families created through shared experience on the inside, could be harnessed to strengthen the resolve of ex-prisoners to not to reoffend after they are released. This would involve not only nourishing existing relational ties in ways that foster prosociality in the community but also eliminating institutionalised practices rife within the criminal justice system that incentivise inauthentic identities and obstruct the capacity of fusion to foster behaviour change. Second, we have argued that fusion between ex-offenders and receiving communities also has a crucial role to play in reducing recidivism and that this can be fostered through initiatives that emphasise shared experiences of various kinds. Many existing initiatives do this already, but greater awareness of the psychological mechanisms involved could lead to refinements that increase the effectiveness of interventions. Finally, we have argued that fusion in society at large has a role to play in shifting public opinion towards a less punitive and more restorative view of prisoner reform, one that emphasises common humanity and the need to reintegrate rather than segregate.

It is not difficult to find examples of criminal justice or corrections approaches that are contrary to what we propose. These would include the requirement in the United Kingdom for people serving community service orders to wear fluorescent bibs identifying them as 'offenders' (Maruna and King 2008), in the United States the growing reliance on community notification laws for managing sex offenders (Lussier and Mathesius 2019), and the recent movement to 'toughen up' the use of parole and conditional release for prisoners in Australia (Freiberg et al. 2018). None of these approaches create avenues for offenders' fusion to others in the community, nor do they tap into the community's willingness to receive (connect with) those who have violated laws. In fact, each of these approaches reflects the dominant politics of 'riskthinking' as well as a presumed community desire for 'revenge and retribution, anger, bitterness and moral indignation' rather than 'shared belief in redemption, the need for second chances, and the belief that all people can change' (Maruna and King 2008: 347).

We have argued that reforming felons and reintegrating them after they are released from prison is best achieved by fostering a sense of shared experience binding them to each other, to receiving communities, and to society at large. When it comes to identity fusion, it is clear that some kinds of transformative life events are more impactful than others. Above all, what matters are the memories that shape our sense of who we are as individuals and the extent to which those self-defining experiences are shared by groups. In our view, efforts at reforming offenders that incentivise or impose inauthentic identities are doomed to fail. Instead, we recommend building interventions that emphasise genuinely shared experiences among ex-offenders and the communities into which they need to be reintegrated.

\section{Acknowledgements}

We would like to thank Michael Buhrmester for comments on an early draft of this article and for contributions to the design of our questionnaire for parolees in Australia, from which interview data is quoted. This work was supported by an Economic and Social Research Council (ESRC) Large Grant entitled 'Ritual, Community, and Conflict' (REF RES060-25-0085) and an Advanced Grant entitled 'Ritual Modes: Divergent Modes of Ritual, Social Cohesion, Prosociality, and Conflict' (agreement no. 694986) from the European Research Council (ERC) under the European Union's Horizon 2020 Research and Innovation Programme.

Harvey Whitehouse is an anthropologist who studies the role of ritual in creating social cohesion and motivating cooperation. He has become increasingly interested in applying the insights of this research to practical problems, such as countering violent ex- 
tremism, fostering wildlife conservation, and reducing recidivism among ex-offenders. He is Professor of Social Anthropology and Fellow of Magdalen College at the University of Oxford.

E-mail: harvey.whitehouse@anthro.ox.ac.uk

Robin Fitzgerald is a criminologist whose research focuses on criminal justice responses to crime, including the uneven effects of correctional policy and practices. Her research interests also include desistance from crime and offender reintegration. She has received research funding from the Australian Research Council for projects on parole and domestic violence law reform. She is Senior Lecturer in Criminology at the School of Social Science at the University of Queensland.

E-mail: robin.fitzgerald@uq.edu.au

\section{Notes}

1. http://www.uservoice.org/about-us/our-services/ peer-support/.

2. http://www.uservoice.org/ex-offender/real-stories/.

3. https://greyston.org/open-hiring/.

4. https://greyston.org/about/.

5. Ibid.

6. https://www.bbc.co.uk/sport/football/46970691.

\section{References}

Andrews D. A. and J. Bonta (2010), The Psychology of Criminal Conduct, 5th ed. (Newark, NJ: LexisNexis).

Australian Bureau of Statistics (2017), Prisoners in Australia, 2017, 'Table 14: Prisoners Selected Characteristics by State/Territory', data cube: cat no. 4517.0, http://www.abs.gov.au/AUSSTATS/abs@.nsf/Details Page/4517.02017?OpenDocument (accessed 15 Feb 2019).

Barth, F. (2002), 'Review of Arguments and Icons', Journal of Ritual Studies 16, no. 2: 14-17, https:// www.jstor.org/stable/44364135.

Bayly, S. (2004), 'Conceptualizing from Within: Divergent Religious Modes from Asian Modernist Perspectives', in Ritual and Memory: Toward a Comparative Anthropology of Religion, (eds) H. Whitehouse and J. Laidlaw (Walnut Creek, CA: AltaMira Press), 111-134.

Becker, H. (1963), Outsiders. New York: Free Press.

Bloch, M. (2004), 'Ritual and Deference', in Ritual and Memory: Toward a Comparative Anthropology of Religion, (eds) H. Whitehouse and J. A. Laidlaw (Walnut Creek, CA: AltaMira Press), 65-78.
Buhrmester, M., D. Burnham, D. Johnson, O. S. Curry, D. Macdonald and H. Whitehouse (2018), 'How Moments Become Movements: Shared Outrage, Group Cohesion, and the Lion that Went Viral', Frontiers in Ecology and Evolution 6: 1-7, doi:10.3389/ fevo.2018.00054.

Conway, M. A. (1995), Flashbulb Memories: Essays in Cognitive Psychology (Hillsdale, NJ: Lawrence Erlbaum Associates, Inc.).

Cullen, F. T. and P. Gendreau (2001), 'From Nothing Works to What Works: Changing Professional Ideology in the 21st Century', The Prison Journal 81, no. 3: 313-338, doi:10.1177/0032885501081003002.

Devilly, G. J., L. Sorbello, L. Eccleston and T. Ward (2005), 'Prison-Based Peer-Education Schemes', Aggression and Violent Behavior 10, no. 2: 219-240, doi:10.1016/j.avb.2003.12.001.

Durose, M. R., A. D. Cooper and H. N. Snyder (2014), Recidivism of Prisoners Released in 30 States in 2005: Patterns from 2005 to 2010. Washington, DC: US Department of Justice, Office of Justice Programs, Bureau of Justice Statistics.

Farrall, S. (2002), Rethinking What Works with Offenders. New York: Routledge.

Freiberg, A., L. Bartels, R. Fitzgerald and S. Dodd (2018), 'Parole, Politics and Penal Policy', QUT L. Rev 18, no. 1: 191-215, doi:10.5204/qutlr.v18i1.680.

Giordano, P. C., S. A. Cernokovich and J. L. Rudolph (2002), 'Gender, Crime and Desistance: Toward a Theory of Cognitive Transformation', American Journal of Sociology 107 no. 4: 990-1064, doi:10.1086/ 343191.

Gómez, A., M. Brooks, M. Buhrmester, A. Vázquez, J. Jetten and W. B. Swann (2011), 'On the Nature of Identity Fusion: Insights into the Construct and a New Measure', Journal of Personality and Social Psychology 100, no. 5: 918-933, doi:10.1037/a0022642.

Goody, J. (2004), 'Is Image to Doctrine as Speech to Writing? Modes of Communication and the Origins of Religion', in Ritual and Memory: Toward a Comparative Anthropology of Religion, (eds) H. Whitehouse and J. Laidlaw (Walnut Creek, CA: AltaMira Press), 49-64.

Graham H., S. Graham and J. Field (2015), 'Returning Citizens: A Quiet Revolution in Prisoner Reintegration', Scottish Justice Matters 3, no. 1: 32-33, http:// hdl.handle.net/1893/21615.

Hallett, M. A., J. Hays, B. R. Johnson, S. J. Jang and G. Duwe (2017), The Angola Prison Seminary: Effects of Faith-based Ministry on Identity Transformation, Desistance, and Rehabilitation. New York: Routledge.

Healy, D. (2014), 'Becoming a Desister: Exploring the Role of Agency, Coping and Imagination in the Construction of a New Self', British Journal of Criminology 54, no. 5: 873-891, doi:10.1093/bjc/azu048. 
Heseltine K., R. Sarre and D. Andrew (2011), 'PrisonBased Correctional Rehabilitation: An Overview of Intensive Interventions for Moderate to High-Risk Offenders', Trends $\mathcal{E}$ Issues in Crime and Criminal Justice 412: 1-6, https://aic.gov.au/publications/tandi/ tandi412.

Hoeve M., J. S. Dubas, V. I. Eichelsheim, P. H. Van der Laan, W. Smeenk and J. R. Gerris (2009), 'The Relationship Between Parenting and Delinquency: A Meta-Analysis', Journal of Abnormal Child Psychology 37, no. 6: 749-775, doi:10.1007/s10802-009-9310-8.

Hofmann, S. G., A. Asnaani, I. J. Vonk, A. T. Sawyer and A. Fang (2012), 'The Efficacy of Cognitive Behavioral Therapy: A Review of Meta-Analyses', Cognitive Therapy and Research 36, no. 5: 427-440, doi:10.1007/s10608-012-9476-1.

Howe, L. (2004), 'Late Medieval Christianity, Balinese Hinduism, and the Doctrinal Mode of Religiosity', in Ritual and Memory: Toward a Comparative Anthropology of Religion, (eds) H. Whitehouse and J. Laidlaw (Walnut Creek, CA: AltaMira Press), 135-145.

Jang, S. J., B. R. Johnson, J. Hays, M. Hallett and G. Duwe (2018), 'Religion and Misconduct in "Angola" Prison: Conversion, Congregational Participation, Religiosity, and Self-Identities', Justice Quarterly 35, no. 3: 412-442, doi:10.1080/07418825.2017.1309057.

Johnson, B. R., M. E. Pagano, M. T. Lee and S. G. Post (2018), 'Alone on the Inside: The Impact of Social Isolation and Helping Others on AOD Use and Criminal Activity', Youth \& Society 50, no. 4: 529550, doi:10.1177/0044118X15617400.

Jong J., H. Whitehouse, C. Kavanagh, and J. Lane (2015), 'Shared Negative Experiences Lead to Identity Fusion via Personal Reflection', PloS ONE 10, no. 12: e0145611, doi:10.1371/journal.pone.0145611.

Kavanagh, C. M., J. Jong, R. McKay and H. Whitehouse (2018), 'Positive Experiences of High Arousal Martial Arts Rituals Are Linked to Identity Fusion and Costly Progroup Actions', European Journal of Social Psychology 49, no. 3: 461-481, doi:10.1002/ ejsp.2514.

Kendall, K. (2002), 'Time to Think about Cognitive Behavioural Programmes', in Women and Punishment: The Struggle for Justice, (ed.) P. Carlen (Devon, UK: Willan Publishing), 182-198.

Laidlaw, J. (2004), 'Embedded Modes of Religiosity in Indic Renouncer Religions', in Ritual and Memory: Toward a Comparative Anthropology of Religion, (eds) H. Whitehouse and J. A. Laidlaw (Walnut Creek, CA: AltaMira Press), 89-110.

LeBel, T. P., R. Burnett, S. Maruna and S. Bushway (2008), "The "Chicken and Egg" of Subjective and Social Factors in Desistance from Crime', European Journal of Criminology 5, no. 2: 131-159, doi:10.1177/1477370807087640.
Lewis, G. (2004), 'Religious Doctrine or Experience: A Matter of Seeing, Learning, or Doing', in Ritual and Memory: Toward a Comparative Anthropology of Religion, (eds) H. Whitehouse and J. A. Laidlaw (Walnut Creek, CA: AltaMira Press), 155-167.

Lussier, P. and J. Mathesius (2019), 'Not in My Backyard: Public Sex Offender Registries and Public Notification Laws', Canadian Journal of Criminology and Criminal Justice 61, no. 1: 105-116, doi:10.3138/ cjccj.2018-0026.

MacKenzie, D. L. (2006), What Works in Corrections: Reducing the Criminal Activities of Offenders and Delinquents. New York: Cambridge University Press.

Martinson, R. (1974), 'What Works? Questions and Answers about Prison Reform', The Public Interest 35: 22-54, https://fbaum.unc.edu/teaching/articles/ Martinson1974.pdf.

Maruna, S. (2001), Making Good: How Ex-Convicts Reform and Rebuild Their Lives. Washington, DC: American Psychological Association.

Maruna, S. and A. King (2008), 'Selling the Public on Probation: Beyond the Bib', Probation Journal 55, no. 4: 337-351, doi:10.1177/0264550508096491.

Maruna, S. and T. P. LeBel (2012), 'The Desistance Paradigm in Correctional Practice: From Programmes to Lives', in Offender Supervision, (eds) F. McNeill, P. Raynor and C. Trotter (London: Willan), 91-114.

McNeill, F. (2006), 'A Desistance Paradigm for Offender Management', Criminology \& Criminal Justice 6, no. 1: 39-62, doi:10.1177/1748895806060666.

Nellis, M. (2009), 'The Aesthetics of Redemption: Released Prisoners in American Film and Literature', Theoretical Criminology 13, no. 1: 129-146, doi:10.1177/1362480608100176.

Newson, M., M. D. Buhrmester and H. Whitehouse (2016), 'Explaining Lifelong Loyalty: The Role of Identity Fusion and Self-Shaping Group Events', PLOS ONE 11, no. 8: 1-13, doi:10.1371/journal.pone .0160427 .

Norris, J. (2016), 'Study Reveals Faith-Based Ministry Impact at America's Largest MaximumSecurity Prison'. University of North Florida, 6 December, https://www.unf.edu/publicrelations/ media_relations/press/2016/Study_Reveals_FaithBased_Ministry_Impact_at_America_s_Largest_ Maximum-Security_Prison.aspx.

Opsal, T. (2012), "'Livin' on the Straights": Identity, Desistance, and Work among Women Postincarceration', Sociological Inquiry 82, no. 3: 378-403, doi:10.1111/j.1475-682X.2012.00421.x.

Peel, J. D. Y. (2004), 'Modes of Religiosity in West Africa', in Ritual and Memory: Toward a Comparative Anthropology of Religion, (eds) H. Whitehouse and J. A. Laidlaw (Walnut Creek, CA: AltaMira Press), 11-30. 
Petersilia, J. (2003), When Prisoners Come Home: Parole and Prisoner Reentry. New York: Oxford University Press.

Pogrebin, M. R., P. B. Stretesky, A. Walker and T. Opsal (2015), 'Rejection, Humiliation, and Parole: A Study of Parolees' Perspectives', Symbolic Interaction 38, no. 3: 413-430, doi:10.1002/symb.164.

Purvis, M., T. Ward and G. Willis (2011), 'The Good Lives Model in Practice: Offence Pathways and Case Management', European Journal of Probation 3, no. 2: 4-28, doi:10.1177/206622031100300202.

Reddish, P., J. Jong, J. A. Lanman, E. M. Tong and H. Whitehouse (2016), 'Collective Synchrony Increases Prosociality towards Non-Performers and Outgroup Members', British Journal of Social Psychology 55, no. 4: 722-738, doi:10.1111/bjso.12165.

Roman, C. G., S. Decker and D. C. Pyrooz (2017), 'Leveraging the Pushes and Pulls of Gang Disengagement to Improve Gang Intervention: Findings from Three Multi-Site Studies and a Review of Relevant Gang Programs', Journal of Crime and Justice 40, no. 3: 316-336, doi:10.1080/0735648X.2017.1345096.

Segal, K., J. Jong and J. Halberstadt (2018), 'The Fusing Power of Natural Disasters: An Experimental Study', Self E Identity 17, no. 5: 574-586, doi:10.1080/ 15298868.2018.1458645.

Stone, R., M. Morash, M. Goodson, S. Smith and J. Cobbina (2018), 'Women on Parole, Identity Processes, and Primary Desistance', Feminist Criminology 13, no. 4: 382-403, doi:10.1177/1557085116670004.

Swann, W. B. and M. Buhrmester (2015), 'Identity Fusion', Current Directions in Psychological Science 24, no. 1: 52-57, doi:10.1177/0963721414551363.

Swann, W. B., M. D. Buhrmester, Á. Gómez, J. Jetten, B. Bastian, A. Vázquez . . . and G. Finchilescu (2014), 'What Makes a Group Worth Dying For? Identity Fusion Fosters Perception of Familial Ties, Promoting Self-Sacrifice', Journal of Personality and Social Psychology 106, no. 6: 912-926, doi:10.1037/a0036089.

Swann, W. B., Á. Gómez, D. C. Seyle, J. Morales and C. Huici (2009), 'Identity Fusion: The Interplay of Personal and Social Identities in Extreme Group Behavior', Journal of Personality and Social Psychology 96, no. 5: 995-1011, doi:10.1037/a0013668.

Swann, W. B., J. Jetten, Á. Gómez, H. Whitehouse and B. Bastian (2012), 'When Group Membership Gets Personal: A Theory of Identity Fusion', Psychological Review 119, no. 3: 441-456, doi:10.1037/a0028589.

Vázquez, A., Á. Gómez, J. R. Ordoñana, W. B. Swann and H. Whitehouse (2017), 'Sharing Genes Fosters Identity Fusion and Altruism', Self $\mathcal{E}$ Identity 16, no. 6: 684-702, doi:10.1080/15298868.2017.1296887.

Western, B., J. R. Kling and D. F. Weiman (2001), 'The Labor Market Consequences of Incarceration', Crime and Delinquency 47, no. 3: 410-427, doi:10.1177/00111 28701047003007.
White, R. and H. Graham (2015), 'Greening Justice: Examining the Interfaces of Criminal, Social and Ecological Justice', British Journal of Criminology 55, no. 5: 845-865, doi:10.1093/bjc/azu11.

Whitehouse, H. (1992), 'Memorable Religions: Transmission, Codification, and Change in Divergent Melanesian Contexts', Man (N.S.) 27, no. 3: 777-797. Reprinted in P. Pachis and D. Wiebe (eds) 2014, In the Sights of History and the Cognitive Sciences (Bristol, UK: Equinox Publishing), 479-510.

Whitehouse, H. (1995), Inside the Cult: Religious Innovation and Transmission in Papua New Guinea (Oxford: Oxford University Press).

Whitehouse, H. (1996), 'Rites of Terror: Emotion, Metaphor, and Memory in Melanesian Initiation Cults', Journal of the Royal Anthropological Institute (N.S.) 2, no. 4: 703-715. Reprinted in John Corrigan (ed.) 2004, Religion and Emotion: Approaches and Interpretations (Oxford: Oxford University Press). 133-148.

Whitehouse, H. (2004), Modes of Religiosity: A Cognitive Theory of Religious Transmission (Walnut Creek, CA: AltaMira Press).

Whitehouse, H. (2013), 'Three Wishes for the World (with Comment)', Cliodynamics: The Journal of Theoretical and Mathematical History 4, no. 2: 281-323, https://escholarship.org/uc/item/2wv6r7v3.

Whitehouse, H. (2018), 'Dying for the Group: Towards a General Theory of Extreme Self-Sacrifice', Behavioral and Brain Sciences 41: 1-62, doi:10.1017/ S0140525X18000249.

Whitehouse H., J. Jong, M. D. Buhrmester, Á. Gómez, B. Bastian, C. M. Kavanagh, M. Newson, M. Matthews, J. A. Lanman, R. McKay and S. Gavrilets (2017), 'The Evolution of Extreme Cooperation via Intense Shared Experiences', Nature: Scientific Reports 7, doi:10.1038/srep44292.

Whitehouse, H. and J. A. Laidlaw (eds) (2007), Religion, Anthropology and Cognitive Science (Durham, NC: Carolina Academic Press).

Whitehouse, H. and J. Lanman (2014), 'The Ties That Bind Us: Ritual, Fusion, and Identification', Current Anthropology 55, no. 6: 1-23, doi:10.1086/678698.

Whitehouse, H., B. McQuinn, M. Buhrmester and W. B. Swann (2014). 'Brothers in Arms: Libyan Revolutionaries Bond Like Family', Proceedings of the National Academy of Sciences 111, no. 50: 17783-17785, www.pnas.org/cgi/doi/10.1073/pnas.1416284111.

Yustisia, W., I. Eka Putra, A. Rufaidah, H. Whitehouse and C. Kavanagh (2019), 'The Role of Religious Fundamentalism and Tightness-Looseness in Promoting Collective Narcissism and Extreme Group Behavior', Psychology of Religion and Spirituality 12, no. 2: 231-240, doi:10.1037/rel0000269. 